\title{
The effect of olive leaf extract on digestive enzyme inhibition and insulin production in streptozotocin-induced diabetic rats
}

\author{
Mehmet Ali TEMIZ1 ${ }^{1}$, Atilla TEMUR ${ }^{2}$ \\ ${ }^{1}$ Karamaoğlu Mehmetbey University, Vocational School of Technical Sciences, Programme of Medicinal and Aromatic Plants, \\ Karaman; ${ }^{2}$ Van Yuzuncu Yil University, Faculty of Education, Department of Mathematics and Sciences, Van, Turkey.
}

\begin{abstract}
Summary: Olive leaf has natural bioactive compounds, mainly oleuropein, that are widely considered to have potentially beneficial effects on health. This study aimed to evaluate the effects of olive leaf extract (OLE) on the inhibition of carbohydrate digestive enzymes, and immunohistochemical study of insulin in the pancreas of in vivo streptozotocin-induced diabetic rats. Blood glucose levels, insulin, glycated hemoglobin $\left(\mathrm{HbA}_{\mathrm{cc}}\right), \alpha$-amylase and $\alpha$-glucosidase activities, and an immunohistochemical study were performed at the end of the experiment. In the OLE treated group, blood glucose levels and $\mathrm{HbA}_{1 \mathrm{c}}$ significantly decreased while insulin levels increased. Besides this, OLE treated group showed remarkable inhibitory activities on $\alpha$-amylase and $\alpha$-glucosidase compared with the Acarbose treated group. It was observed that OLE exhibited partial positive immunoreaction for insulin in $\beta$-cells through immunohistochemical analysis. Considering that OLE is more tolerable for digestion system compared to acarbose, it may be a better fitoformulation for antidiabetic medications. OLE could offer an additional beneficial effect for the treatment of diabetes.
\end{abstract}

Keywords: $\alpha$-amylase, $\alpha$-glucosidase, hypoglycemic, immunohistochemistry, olive leaf.

\section{Streptozotosin ile indüklenmiş diyabetik sıçanlarda zeytin yaprağı ekstraktının sindirim enzimi inhibisyonuna ve insülin üretimine etkisi}

Özet: Zeytin yaprağı potansiyel olarak sağlık üzerine yararlı etkileri olduğu düşünülen başlıca oleuropein olmak üzere biyoaktif bileşenlere sahiptir. Bu çalışma, streptozotosin (STZ) ile indüklenmiş diyabetik sıçanlarda zetin yaprağı ekstraktının (OLE) in vivo karbonhidrat sindirim enzimleri inhibisyonunun ve pankreasta insülin mevcudiyetinin araştırılmasını amaçlamaktadır. Deney sonunda kan glukoz seviyeleri, insülin seviyeleri, glikozillenmiş hemoglobin $\left(\mathrm{Hb}_{1 c}\right), \alpha$-amilaz ve $\alpha$-glukozidaz aktiviteleri analizi ile immunohistokimyasal çalışma yapıldı. OLE tedavi grubunda kan glukoz seviyeleri ve $\mathrm{Hb}_{1 c}$ anlamlı şekilde azalırken insülin seviyeleri arttı. Bunun yanında OLE, Akarboz grubuna göre dikkat çekici şekilde $\alpha$-amilaz ve $\alpha$-glukozidaz aktivitelerinde inhibitör etki gösterdi. Immunohistokimyasal analizde OLE’nin $\beta$-hücrelerinde insülin için kısmi pozitif immunoreaksiyon gösterdiği gözlendi. OLE akarboz ile karşılaştırıldığında sindirim sistemi bakımından daha tolere edilebilir olduğu düşünüldüğünde antidiyabetik ilaçlara göre daha iyi bir fitoformülasyon olabilir. OLE, diyabet tedavisi için ek bir faydalı etki sunabilir.

Anahtar sözcükler: $\alpha$-amilaz, $\alpha$-glukozidaz, hipoglisemi, immunohistokimya, zeytin yaprağı.

\section{Introduction}

Diabetes mellitus is a heterogeneous metabolic syndrome characterized by hyperglycemia caused by a relative or absolute deficiency of insulin (11). Insulin action deficiency, a common case of diabetes, leads to impairment of carbohydrate, lipid and protein metabolism. Furthermore, insulin resistance plays a role in the pathogenesis of hyperglycemia and diabetes in tissues and cells (10). Hyperglycemia developing with impaired fasting glucose and glucose tolerance leads to serious macrovascular and microvascular diabetic complications. In addition, increased reactive oxygen species play a substantial role in the development of diabetes complications (25). Therefore, the control of blood glucose levels in diabetes is very important.
Recently, scientific studies have proven that many phytochemicals are effective both to prevent and treat diseases. The health benefits of phytochemicals depend on the amount consumed and on their bioactivity, for this reason, nutraceutical and therapeutical usage have become popular (20). The pharmacological properties of the fruit of the olive tree and its products have been defined as important components of a healthy diet due to their bioactive phenolic content (21). Nevertheless, olive leaves contain higher amounts of polyphenols than olive oil. For example, oleuropein is the main phenolic compound and the most active phenolic compound in olive leaf (23).

Although, several studies revealed that olives and olive leaf have an antihyperglycemic effect, but there is no information with respect to the inhibition effects of $\alpha$ - 
amylase and $\alpha$-glucosidase and amelioration of $\beta$-cells in vivo. Therefore, this study aimed to investigate the effect of olive leaf extract (OLE) on $\alpha$-amylase and $\alpha$ glucosidase enzymes inhibition and insulin production of $\beta$-cells on in vivo experimental diabetes.

\section{Materials and Methods}

All chemicals and reagents used in the study were analytical grade and obtained from Sigma Inc. (St. Louis, MO).

Olive leaf extract: Olive (Olea europaea L.) leaves were collected from Antalya, Turkey, in August 2013. They were then dried and powdered to make the olive leaf extract. The extract was composed of $1 \mathrm{~g}$ of powder combined with $50 \mathrm{~mL}$ of distilled water. The extraction process was carried out on a magnetic hot plate (Wisd WiseStir MSH-20D) for a period of 12 hours at $80^{\circ} \mathrm{C}$ and $750 \mathrm{rpm}$. Then, it was filtered and placed in a centrifuge (Hettich Universal 320r) for 5 minutes at $4^{\circ} \mathrm{C}, 3500 \mathrm{rpm}$ in a falcon tube. The final extract obtained was transferred to vials in order to carry out content analysis. The extraction was carried out in duplicate. OLE was evaporated under reduced pressure to administer for study. Furthermore, $1.5 \mathrm{~g}$ of leaf sample was infused in $100 \mathrm{ml}$ of water at $80^{\circ} \mathrm{C}$ for 5 minutes to create a homemade extract.

Determination of extract content by HPLC: The amounts of oleuropein, hydroxytyrosol, tyrosol and verbascoside in the sample were measured quantitatively against external standards in extracted olive leaves. A Waters 1525 binary HPLC pump and Waters 2487 dual absorbance detector were used for content analysis. The measurement was made by adjusting chromatogram to $280 \mathrm{~nm}$ wavelengths for the determination and assignment of polyphenolic compounds.

Animals: Experiments were performed on 40 male rats (Wistar albino, 250-350 g and 5-6 months of age) obtained from Experimental Application and Research Center, Yuzuncu Yil University (Turkey). The rats were housed in five groups $(\mathrm{n}=8)$ at $20 \pm 2{ }^{\circ} \mathrm{C}$ with $12: 12 \mathrm{~h}$ reverse light/dark cycle in stainless cages and fed standard chow ad libitum and water for 21 days. This investigation was approved by the Yuzuncu Y1l University Animal Researches Local Ethic Committee (no. 2015/08).

Experimental protocol: Blood glucose levels were measured by using a glucometer (Accu Check Nano, Germany) in tail bloods, and monitored periodically every week. Streptozotocin (STZ) was administered at $45 \mathrm{mg} / \mathrm{kg}$ intraperitonally (i.p.) (13). Blood glucose levels were measured in tail bloods at 3 days after STZ injection. Rats with glucose levels $\geq 200 \mathrm{mg} / \mathrm{dL}$ were considered diabetic. Control Group (CG): Rats were given a single dose of 1 $\mathrm{mL}$ citrate buffer. Diabetic Group (DG): Rats were given a single dose of $45 \mathrm{mg} / \mathrm{kg}$ body weight (bw) i.p STZ.
Diabetic $+O L E(O L E)$ : Diabetic rats were treated with 25 $\mathrm{mg} / \mathrm{kg}$ bw OLE daily using an intragastric tube. Diabetic+Infusion (Inf): Diabetic rats were treated with 1 $\mathrm{mL}$ infusion solution daily using an intragastric tube. Diabetic + Acarbose $(A c)$ : Diabetic rats were treated with $150 \mathrm{mg} / \mathrm{kg}$ bw Glucobay (Bayer, Turkey) daily using an intragastric tube.

Infusion and acarbose group designed for comparison of only biochemical analysis and monitoring blood glucose level.

The rats were anesthetized with ketamine+xylazine and then blood and tissue samples were collected at the end of the experiment. The pancreas and intestinal tissues were removed and rinsed with physiological saline.

Biochemical analysis: Insulin levels were measured with electrochemiluminescence immunoassay (ECLIA) method (Architect İ4000SR, Abbott Laboratories Inc.). $\mathrm{HbA}_{1 \mathrm{c}}$ was determined using automatic glycohemoglobin analyzer based on HPLC (ADAMS A1c HA-8180T, Akray Inc.).

Determination of $\alpha$-amylase and $\alpha$-glucosidase activities: $\alpha$-Amylase activity was measured with AlphaAmylase Assay kit (Abnova) by using the spectrophotometric method (Boeco S-22 UV-Vis) as specified by the supplier. An insoluble dye-coupled substrate amylose azure was cleaved by $\alpha$-amylase into soluble colored products. The color intensity was measured at $595 \mathrm{~nm}$ in the sample.

$\alpha$-Glucosidase activity was measured with AlphaGlucosidase Assay kit (Assay bioTech) by using the spectrophotometric method (Biochrom Anthos Zenyth 200) as specified by the supplier. $\alpha$-Glucosidase reacts with 4-nitrophenyl $\alpha$-D-glucopyranoside and a yellow complex is formed. This complex was measured at 405 $\mathrm{nm}$.

Immunohistochemistry analysis: Pancreatic tissues were fixed and embedded in paraffin. Immunocytochemical reactions were performed by $\mathrm{ABC}$ (avidin biotin complex) (14). Endogenous peroxidase activity was inhibited by $3 \% \mathrm{H}_{2} \mathrm{O}_{2}$ for $30 \mathrm{~min}$ at the deparaffinized section and washed with tap water. The section was blocked by incubation with normal goat serum (DAKO, X 0907, Denmark) with PBS, diluted 1:4 to block non-specific binding. They were incubated with monoclonal insulin (18-0066, Zymed, San Francisco, CA), diluted 1/40 overnight and washed with PBS for 30 $\min$. The sections were incubated with biotinylated antimouse IgG (DAKO LSAB2 Kit) for 30×2 min and washed with PBS. They were incubated AEC (Aminoethylcarbazole Substrate Kit, Zymed Laboratories) for $10 \mathrm{~min}$ and washed with tap water. Counterstaining was performed with hematoxylin and the sections were mounted. The tissue preparations were examined by light microscopy (Leica ICC 50). 
Statistical analysis: Data are expressed as mean $(\overline{\mathrm{X}})$ and standard deviation $( \pm \mathrm{SD})$. Significant differences between groups were assessed using one-way analysis of variance followed by Tukey's test and Tamhane's T2. $p$ value $\leq 0.05$ was accepted as statistically significant.

\section{Results}

The amounts of oleuropein, hydroxytyrosol, tyrosol and verbascoside was determined at 15335.55, 461.05, 41.6 and $357.6 \mu \mathrm{g} / \mathrm{g}$ respectively in OLE by HPLC analysis (Figure 1). The values of blood glucose levels (BGL), insulin, $\mathrm{HbA}_{1 \mathrm{c}}, \alpha$-amylase and $\alpha$-glucosidase activities are shown in Table 1. Blood glucose levels increased in STZ administered groups. The results are shown in Figure 2A. According to the results, BGL was significantly decreased in the OLE-treated group compared to the diabetic group, but it did not decrease significantly in the infusion group. Glycated hemoglobin $\left(\mathrm{HbA}_{1 \mathrm{c}}\right)$ is a form of hemoglobin that was determined $9 \pm 0.4 \%$ in the diabetic group. However, OLE and infusion administration resulted in a decrease of $\mathrm{HbA}_{1 \mathrm{c}}(p$ $<0.05)$ as shown in Figure 2B. In this context there was a strong positive correlation between $\mathrm{BGL}$ and $\mathrm{HbA}_{1 \mathrm{c}}$ in the groups. Although insulin levels decreased in the diabetic group, it remarkably increased in the OLE-treated group (Figure 2C). Activities of the carbohydrate digestive enzymes, $\alpha$-amylase and $\alpha$-glucosidase, are shown in Figure 3A-B. As concerns $\alpha$-amylase and $\alpha$-glucosidase activities, the results of the present study showed that both activities significantly decreased in the OLE group compared with the diabetic group. Remarkably, OLE showed a much more effective reduction in $\alpha$-glucosidase and $\alpha$-amylase activities compared with acarbose. Infusion administration significantly induced a decrease in $\alpha$-amylase activity in comparison with the diabetic group, but there was not a significant decrease in $\alpha$-glucosidase activity. However, it did not display an efficient activity on both enzymes compared with acarbose.

Figure 4 shows the presence of insulin in pancreatic $\beta$-cells. Sections were counterstained with immunoperoxidase-hematoxylin. Insulin positive cells were approved by immunostaining for insulin antibodies. Insulin showed normal expression with respect to the control group (As shown Figure 4A). However, a negative reaction was determined for insulin in Langerhans islets (arrows) in the diabetic group (Figure 4B). On the other hand, the OLE-treated group exhibited partial positive immunoreaction (arrows) for insulin in $\beta$-cells (Figure 4C).

Table 1. Various parameters of control and STZ-induced diabetic rats.

Tablo 1. Kontrol ve STZ ile indüklenmiş diabetik sıçanların çeşitli parametreleri.

\begin{tabular}{llllll}
\hline Analysis & CG & DG & OLE & Inf & Ac \\
\hline Glucose (mg/dL) & $112 \pm 9$ & $566 \pm 37^{\mathrm{a}}$ & $444 \pm 41^{\mathrm{a}, \mathrm{b}}$ & $520 \pm 15^{\mathrm{a}}$ & $511 \pm 28^{\mathrm{a}}$ \\
Insulin (ng/mL) & $0.65 \pm 0.10$ & $0.22 \pm 0.04^{\mathrm{a}}$ & $0.43 \pm 0.06^{\mathrm{a}, \mathrm{b}}$ & $0.32 \pm 0.04^{\mathrm{a}}$ & $0.27 \pm 0.03^{\mathrm{a}}$ \\
$\mathrm{HbA}_{1 \mathrm{c}}(\%)$ & $4.5 \pm 0.2$ & $9 \pm 0.4^{\mathrm{a}}$ & $7.4 \pm 0.2^{\mathrm{a}, \mathrm{b}}$ & $7.7 \pm 0.4^{\mathrm{a}, \mathrm{b}}$ & $8.1 \pm 0.3^{\mathrm{a}, \mathrm{b}}$ \\
$\alpha$-Amylase (U/L) & $1268 \pm 135$ & $1950 \pm 182^{\mathrm{a}}$ & $1063 \pm 87^{\mathrm{b}}$ & $1534 \pm 129^{\mathrm{a}, \mathrm{b}}$ & $1296 \pm 184^{\mathrm{b}}$ \\
$\alpha$-Glucosidase (mU/mL) & $3166 \pm 119$ & $3475 \pm 180^{\mathrm{a}}$ & $2696 \pm 201^{\mathrm{a}, \mathrm{b}}$ & $3364 \pm 104$ & $3132 \pm 122^{\mathrm{b}}$ \\
\hline
\end{tabular}

a: Significantly different from control $(p<0.05){ }^{\text {b: }}$ Significantly different from the DG $(p<0.05)$.

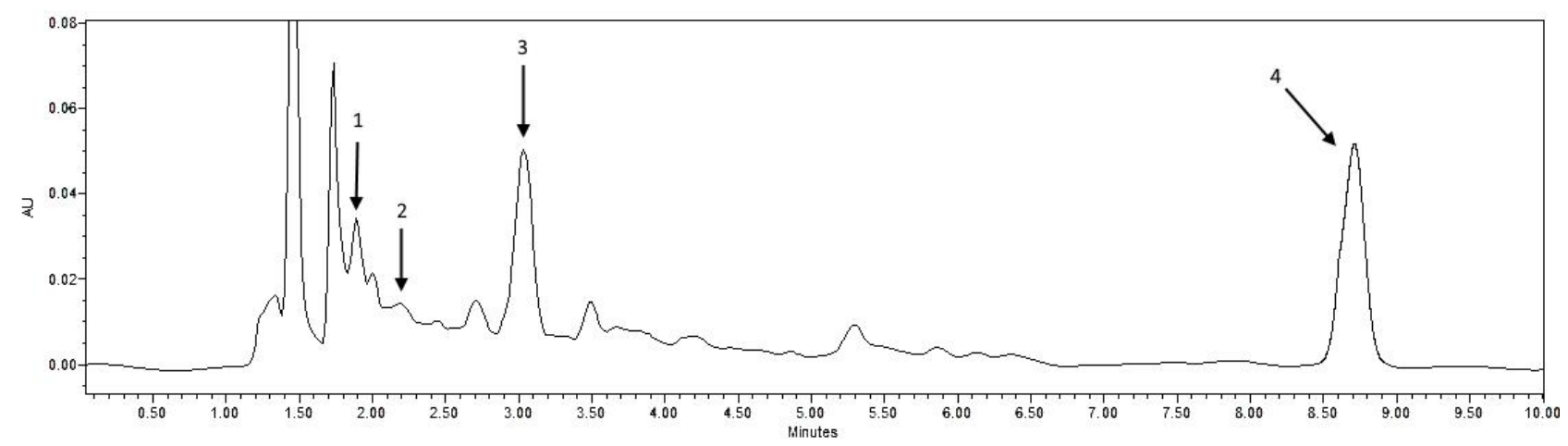

Figure 1. HPLC phenolic profile of OLE at $280 \mathrm{~nm}$. (1) Hydroxytyrosol; (2) Tyrosol; (3) Verbascoside; (4) Oleuropein. Şekil 1. OLE'nin 280 nm'de HPLC fenolik profili. (1) Hidroksitirozol; (2) Tirozol; (3) Verbaskozit; (4) Oleuropein. 

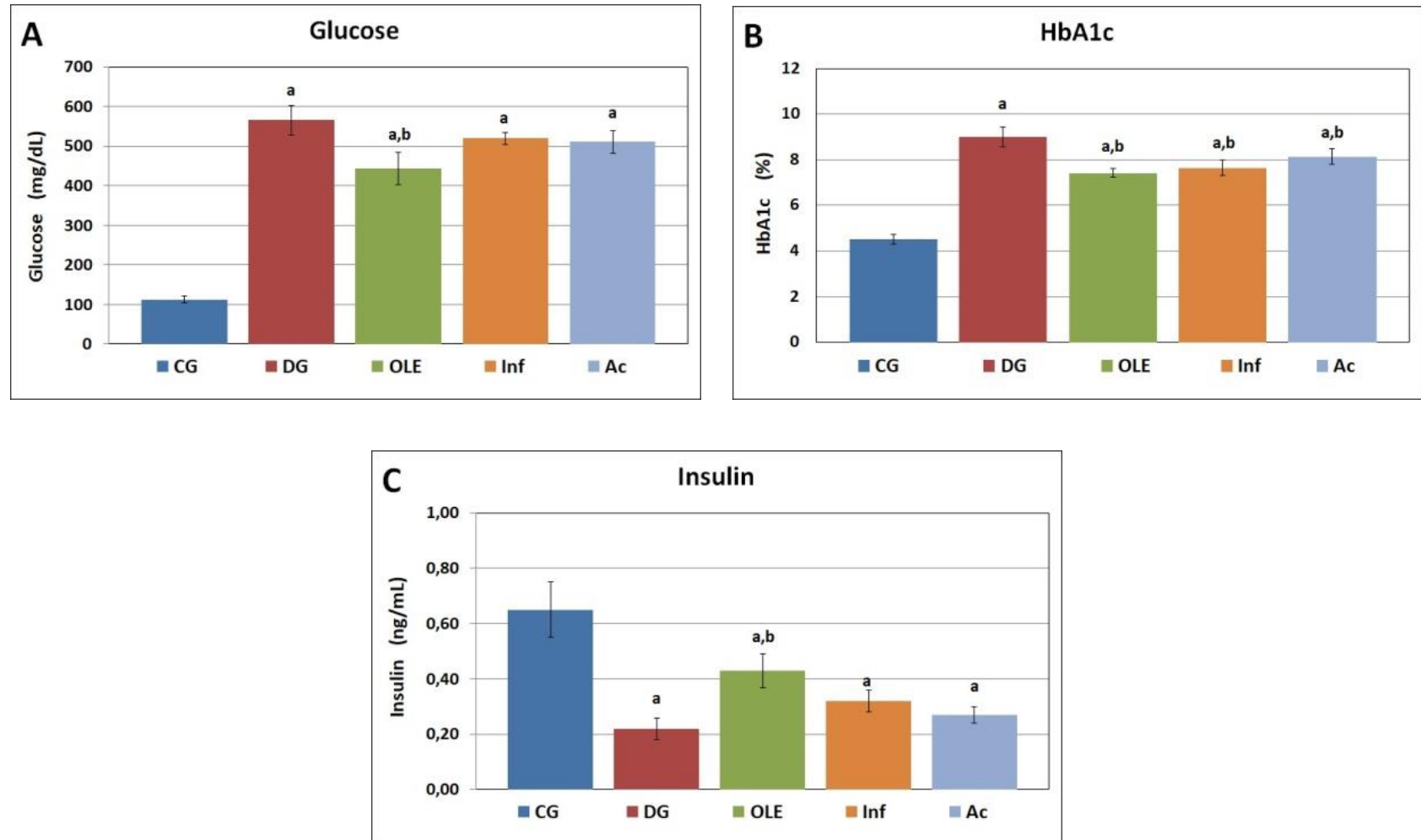

Figure 2. Blood glucose levels (A), $\mathrm{HbA}_{1 \mathrm{c}}$ percentages (B), and Insulin levels (C) of control and STZ-induced diabetic rats.

Şekil 2. Kontrol ve STZ ile indüklenmiş diabetik sıçanların kan glukoz seviyeleri (A), HbA ıc yüzdeleri (B) ve İnsulin seviyeleri (C).

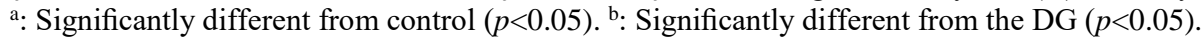
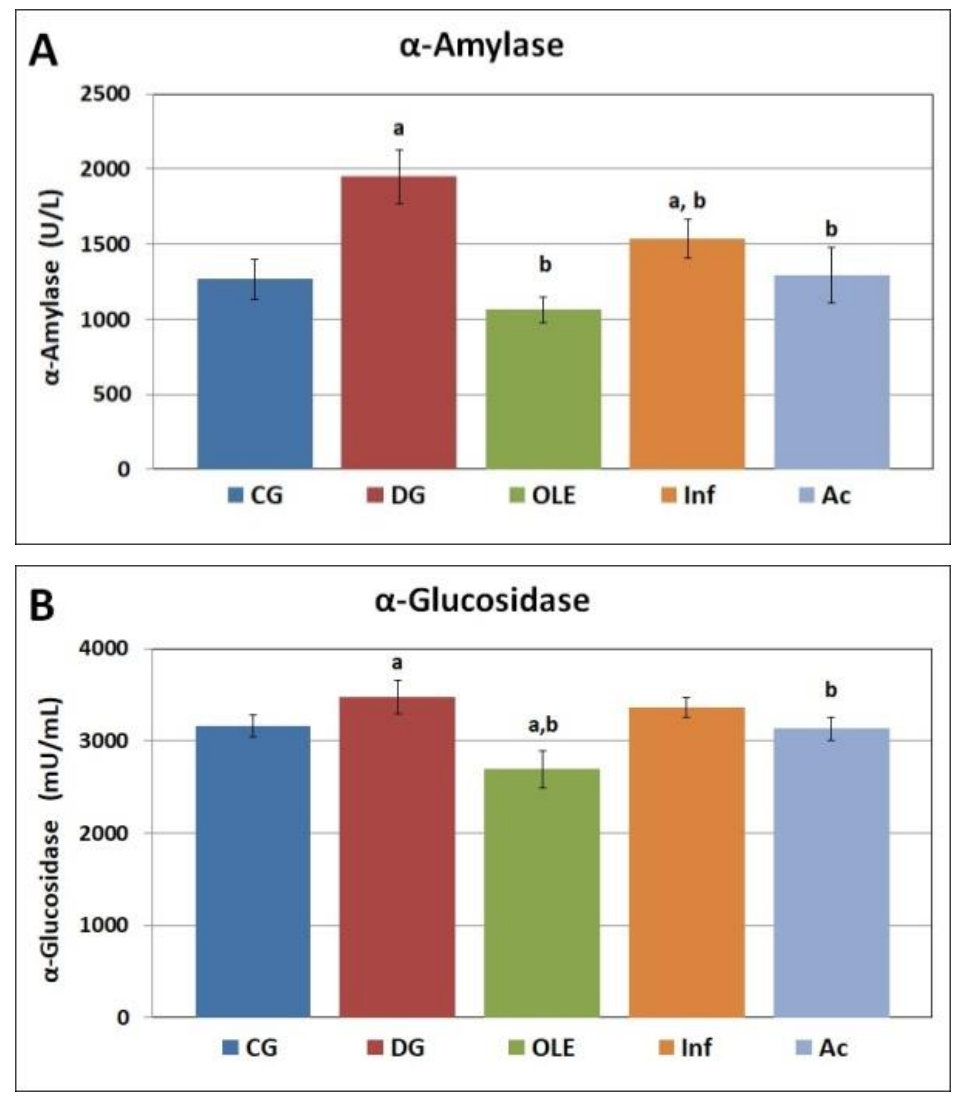

Figure 3. $\alpha$-Amylase (A) and $\alpha$-Glucosidase activities (B) of control and STZ-induced diabetic rats.

Şekil 3. Kontrol ve STZ ile indüklenmiş diabetik sıçanların $\alpha$-Amilaz (A) ve $\alpha$-Glukozidaz aktiviteleri (B).

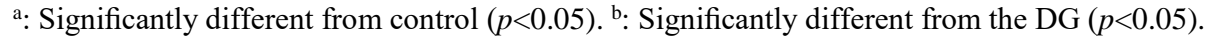



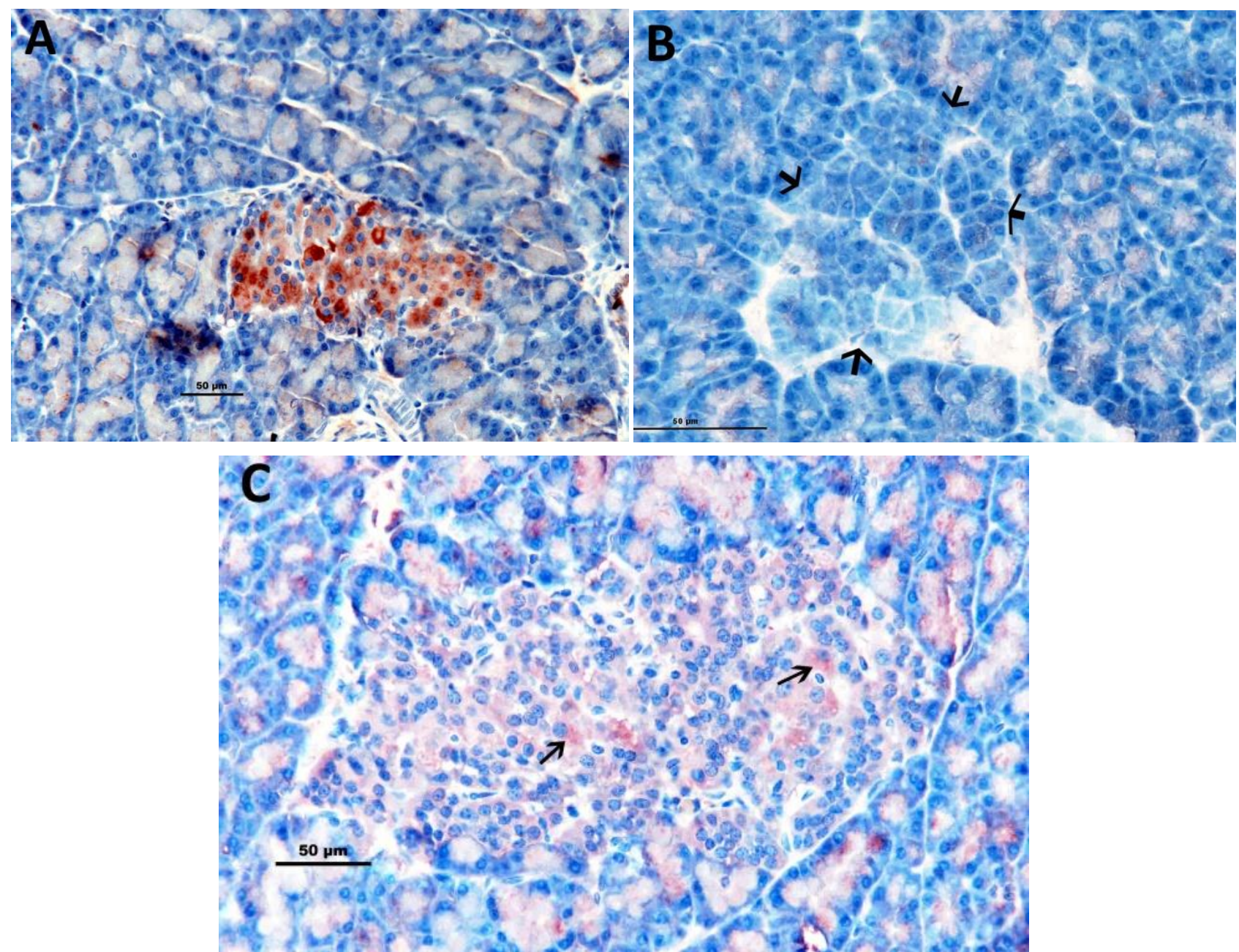

Figure 4. The Control group exhibited positive immunohistochemical reaction of pancreatic $\beta$-cells (A); negative immunohistochemical reaction of pancreatic $\beta$-cells (arrows) in the Diabetic group (B); partial immunohistochemical reaction of pancreatic $\beta$-cells (arrows) in the OLE group (C). Immunoperoxidase-Hematoxylin, Bar $=50 \mu \mathrm{m}$.

Şekil 4. Kontrol grubu pankreatik $\beta$-hücrelerinin pozitif immunohistokimyasal reaksiyonu (A); Diabetik grubta pankreatik $\beta$ hücrelerinin (oklar) negaitf immunohistokimyasal reaksiyonu (B); OLE grubunda pankreatik $\beta$-hücrelerinde (oklar) kısmi immunohistokimyasal reaksiyon (C). İmmunoperoksidaz-Hematoksilen, Bar=50 $\mu \mathrm{m}$.

\section{Discussion and Conclusion}

Recently, plant-based treatments have been considered effective for the prevention and control of diabetes because of their specific biological activities and low toxic effects. Due to these characteristic effects, they may be preferred over various antidiabetic medications (5, 22 ). In the present study, the $\alpha$-amylase and $\alpha$-glucosidase inhibitory effects and $\beta$-cell ameliorative activity of OLE were investigated on STZ-induced diabetic rats in vivo for the first time.

The results showed that a dose of $25 \mathrm{mg} / \mathrm{kg}$ OLE was effective in controlling blood glucose level, which decreased by about $20 \%$. Olive leaf was reported to have a hypoglycemic effect on diabetic rabbits, rats, and humans $(3,12,26)$ which is in agreement with both current findings and previous studies. In the previous study, pancreatic islet cells isolated from allaxon-induced rats were incubated with crude oleuropeoside $(0.2 \mathrm{mg} / \mathrm{mL})$ which purified from olive leaves. As a result, the presence of oleuropeoside in the islet incubation medium together with $2.7 \mathrm{mmol} / \mathrm{L}$ glucose (basal) raised insulin levels (9). Bock et al. (4) reported that OLE improves both insulin sensitivity and pancreatic $\beta$-cell secretory capacity after oral glucose challenge on the overweight males. The findings of current study are consistent with the aforementioned studies in that OLE may be effective in insulin production. Besides, partial positive immunohistochemical findings in the present study corroborate OLE's effect on insulin production. On the other hand, treatment of diabetic rats with OLE significantly decreased $\mathrm{HbA}_{1 c}$. In a previous investigation, Wainstein et al. reported that $\mathrm{HbA}_{1 \mathrm{c}}$ significantly decreased from $10 \%$ to $8.0 \pm 1.5 \%$ in OLE-treated subjects at the end of the 14 weeks in the randomized clinical trial (26). However, Wainstein et al. (26) did not measure the physical activities and diet type of the participants in their 
study, so the independent effect of OLE alone could not be determined. These data confirmed the hypoglycemic and antidiabetic effects of OLE which might be mediated through its $\alpha$-glucosidase and $\alpha$-amylase inhibitory activity.

Previous in vitro studies have indicated that olive oil, olive mill wastewater, and olive leaf extract were effective at the inhibitory concentration $50 \%$ ( $\left.\mathrm{IC}_{50}\right)$ against $\alpha$ glucosidase and $\alpha$-amylase $(6,16,18)$. Furthermore, olive oil exhibited efficient inhibitory activity compared to acarbose because of a richer phenolic content (18). On the basis of these literatures, the results obtained in the present study provided positive support in vivo. A positive correlation was observed in the OLE group when compared to $\alpha$-glucosidase and $\alpha$-amylase enzyme activities with blood glucose level. It was indicated that the blood glucose levels markedly attenuated while the enzyme activities decreased in OLE group. OLE is considered to be effective to decrease blood glucose level by (i) inhibiting activity of carbohydrate digestive enzymes, $\alpha$-glycosidase and $\alpha$-amylase, or (ii) downregulating gene expressions of these enzymes. Antidiabetic medications cause undesirable symptoms due to undigested starch in the colon (7). Thus, tending toward alternative $\alpha$-glucosidase inhibitors that are derived from natural sources and nutrients may be more effective, safe, tolerable and cheaper. Although acarbose administration is known to cause bloating and diarrhea, these symptoms were not observed in the OLE treatment in the present study.

Impaired $\beta$ cells function or structure causes alteration in blood glucose and insulin levels. Based on various immunohistochemical studies conducted on diabetes demonstrated that the density of insulin positive reaction area (24), amount (17) and percentage of $\beta$-cells (15) of diabetic subjects were lower compared to nondiabetic subjects. The antidiabetic activities of medicinal plants depend on the degree of $\beta$ cell destruction and the presence of bioactive contents which show attenuation in the blood glucose level (19). The results obtained in this study revealed that monitored partial positive immunoreaction for insulin in $\beta$ cells at the OLE group may play a role in the reduction of blood glucose due to oleuropein, which is the most bioactive phenolic. In previous studies, phytochemicals have been reported to be effective with different mechanisms in the regeneration of $\beta$-cells $(1,2,8)$. For this reason, the results suggested that OLE may regenerate $\beta$ cells and/or up-regulate insulin expression in intact $\beta$ cells. In this way OLE may exhibit a hypoglycemic effect.

OLE administration significantly improved glycemic status and showed efficient activity for inhibitions of $\alpha$ amylase and $\alpha$-glucosidase. The biochemical and immunohistochemical results revealed that OLE might have a potential agonist and/or antagonist effect for the development of new antidiabetic medications. Considering these effects of OLE, it may be a better alternative phytoformulation in comparison with antidiabetic medications.

\section{Acknowledgement}

This research was supported by the Yuzuncu Yil University Scientific Research Projects Foundation, Van, Turkey (Grant no. FBE-D063).

\section{References}

1. Ahmed ABA, Rao AS, Rao MV (2010): In vitro callus and in vivo leaf extract of Gymnema sylvestre stimulate $\beta$-cells regeneration and anti-diabetic activity in Wistar rats. Phytomedicine, 17, 1033-1039.

2. Alashkham FA, Osman MT, Adnan A, et al. (2013): Histopathological and biochemical effects of Allium Sativum oil administration on type 1 diabetic rats. Res J Pharm Biol Chem Sci, 4 (1), 1045-1053.

3. Al-Azzawie HF, Alhamdani MS (2006): Hypoglycemic and antioxidant effect of oleuropein in alloxan-diabetic rabbits. Life Sci, 78, 1371-1377.

4. de Bock M, Derraik JGB, Brennan JM, et al. (2013): Olive (Olea europaea L.) leaf polyphenols improve insulin sensitivity in middle-aged overweight men: a randomized, placebo-controlled, crossover trial. PLoS ONE, 8 (3), e57622.

5. Buchholz T, Melzig MF (2016): Medicinal plants traditionally used for treatment of obesity and diabetes mellitus - screening for pancreatic lipase and $\alpha$-Amylase inhibition. Phytother Res, 30, 260-266.

6. Cardinali A, Cicco N, Linsalata V, et al. (2010): Biological activity of high molecular weight phenolics from olive mill wastewater. J Agr Food Chem, 58, 8585-8590.

7. Cheng AYY, Fantus IG (2005): Oral antihyperglycemic therapy for type 2 diabetes mellitus. Can Med Assoc J, 172 (2), 213-226.

8. Girija K, Lakshman K, Chandrika U, et al. (2011): Antidiabetic and anti-cholesterolemic activity of methanol extracts of three species of Amaranthus. Asian Pac J Trop Biomed, 1 (2), 133-138.

9. Gonzalez M, Zarzuelo A, Gamez MJ, et al. (1992): Hypoglycemic activity of olive leaf. Planta Med, 58 (6), 513515.

10. Guo S (2014): Insulin signaling, resistance, and metabolic syndrome: insights from mouse models into disease mechanisms. J Endocrinol, 220, T1-T23.

11. Harvey RA, Ferrier DR (2011): Lippincott's Illustrated Reviews: Biochemistry. 337. In: RA Harvey (Ed), Integration of Metabolism: Diabetes Mellitus. $5^{\text {th }}$ ed. Lippincott Williams \& Wilkins, Hong Kong.

12. Jemai H, El Feki A, Sayadi S (2009): Antidiabetic and antioxidant effects of hydroxytyrosol and oleuropein from olive leaves in alloxan-diabetic rats. J Agr Food Chem, 57 (19), 8798-8804.

13. Kamalakkannan N, Prince PSM (2005): The effect of Aegle marmelos fruit extract in streptozotocin diabetes. $\mathbf{J}$ Herb Pharmacother, 5 (3), 87-96. 
14. Kanter M, Uysal H, Karaca T, et al. (2006): Depression of glucose levels and partial restoration of pancreatic $\beta$-cell damage by melatonin in streptozotocin-induced diabetic rats. Arch Toxicol, 80, 362-369.

15. Kawasaki F, Matsuda M, Kanda Y, et al. (2005): Structural and functional analysis of pancreatic islets preserved by pioglitazone in $d b / d b$ mice. Am J PhysiolEndoc M, 288 (3), 510-518.

16. Komaki E, Yamaguchi S, Maru I, et al. (2003): Identification of anti- $\alpha$-Amylase components from olive leaf extracts. Food Sci Technol Res, 9 (1), 35-39.

17. Koyuturk M, Ozsoy-Sacan O, Bolkent S, et al. (2005): Effect of glurenorm on immunohistochemical changes in pancreatic beta cells of rats in experimental diabetes. Indian J Exp Biol, 43 (3), 268-271.

18. Loizzo MR, Lecce GD, Boselli E, et al. (2011): Inhibitory activty of phenolic compounds from extra virgin olive oils on the enzymes involved in diabetes obesity and hypertension. J Food Biochem, 35, 381-399.

19. Mahmoud MF, El Ashry FZZ, El Maraghy NN, et al. (2017): Studies on the antidiabetic activities of Momordica charantia fruit juice in streptozotocin-induced diabetic rats. Pharm Biol, 55 (1), 758-765.

20. Manach C, Scalbert A, Morand C, et al. (2004): Polyphenols: Food sources and bioavailability. Am J Clin Nutr, 79, 727-747.

21. Omar SH (2010): Oleuropein in olive and its pharmacological effects. Sci Pharm, 78, 133-154.
22. Satija A, BhupathirajuSN, Rimm EB, et al. (2016): Plant-based dietary patterns and incidence of type 2 diabetes in US men and women: results from three prospective cohort studies. PLoS Med, 13 (6), 1-18.

23. Servili M, Selvaggini R, Esposto S, et al. (2004): Health and sensory properties of virgin olive oil hydrophilic phenols: agronomic and technological aspects of production that affect their occurrence in the oil. $\mathrm{J}$ Chromatogr A, 1054, 113-127.

24. Shao J, Iwashita N, Ikeda F, et al. (2006): Beneficial effects of candesartan an angiotensin II type 1 receptor blocker on beta-cell function and morphology in $\mathrm{db} / \mathrm{db}$ mice. Biochem Bioph Res Co, 344 (4), 1224-1233.

25. Tangvarasittichai S (2015): Oxidative stress, insulin resistance, dyslipidemia and type 2 diabetes mellitus. World J Diabetes, 6 (3), 456-480.

26. Wainstein J, Ganz T, Boaz M, et al. (2012): Olive leaf extract as a hypoglycemic agent in both human diabetic subjects and in rats. J Med Food, 15, (7) 1-6.

Geliş tarihi: 12.05.2018 / Kabul tarihi: 12.03.2019

\author{
Address for correspondence: \\ Dr. Mehmet Ali TEMIZ \\ Karamanoğlu Mehmetbey University, \\ Vocational School of Technical Sciences, \\ Programme of Medicinal and Aromatic Plants, \\ Karaman, Turkey \\ e-mail:matemiz@kmu.edu.tr
}

